УДК 574.4

\author{
В. А. Горейко \\ Днепровско-Орельский природный заповедник

\section{ЗАЩИТНО-ВОДООХРАННЫЕ ЛЕСА \\ И ИХ ЭКОЛОГИЧЕСКАЯ РОЛЬ В СТЕПНОЙ ЗОНЕ УКРАИНЫ}

Розглянуто функції лісових насаджень у степовій зоні. Досліджено основні види водоохоронних лісів і визначена їх роль у захисті водних джерел від ерозійних процесів. Проаналізовано роль прибалкових лісів.

\author{
V. A. Goreiko \\ Dniprovs'ko-Orels'ky Nature Reserve

\section{WATER PROTECTION FORESTS AND THEIR ECOLOGICAL ROLE IN STEPPE ZONE OF UKRAINE}

Functions of the timber plantings in steppe zone are under consideration. The main types of water-protecting forests are explored. Their role in protection of the water sources from erosive processes is determined. The function of ravine forests is analysed.

\title{
Введение
}

Основной источник обеспечения пресной водой живущих на Земле - реки и озеpa. В настоящее время проблема загрязнения водных объектов (рек, озер, морей, грунтовых вод и т. д.) является наиболее актуальной. Многими учеными доказана положительная гидролого-мелиоративная роль лесных насаждений $[2 ; 22 ; 30]$. Поэтому изучение экологической роли защитно-водоохранных лесов в правобережной части Днепродзержинского водохранилища имеет большое научное и практическое значение. Цель данной работы - охарактеризовать экологическую роль основных видов защитноводоохранных лесов в зоне Днепродзержинского водохранилища.

Объектами исследования послужили защитные лесные насаждения, расположенные в правобережной части Днепродзержинского водохранилища (по направлению Днепродзержинск - Мишурин Рог).

\section{Исторический очерк выделения водоохранно-защитных лесов}

Признание за лесами водоохранно-защитной роли утвердилось очень давно. Первые мероприятия по ограничению рубок леса вдоль рек России относятся к середине XVI века. Более строгие меры в этом отношении позже были приняты Петром I, развивавшим государственное кораблестроение. Однако водоохранно-защитные леса как особую категорию лесов с более регулируемым ведением хозяйства в них фактически стали выделять после принятия в 1888 году лесоохранительного закона. Согласно этому закону все леса европейской части России подразделялись на три категории: защитные, водоохранные и прочие.

(C) В. А. Горейко, 2008 
К защитным относились леса, которые предохраняли берега рек, склоны гор и оврагов от размывания и обвалов, защищали от заносов песком, закрепляли движущиеся пески. Понятие водоохранных лесов было нечетким. К ним относились леса, произрастающие в верховьях рек и по их притокам. В соответствии с лесоустроительным законом в России было выделено лишь 0,6 млн. га водоохранных лесов и столько же защитных. По отчету лесного департамента площадь водоохранных лесов на 1914 год составляла 0,8 млн. га, а защитных - 0,7 млн. га.

В 1916 году был принят закон «О лесах», которым предусматривалось разделение лесов на защитные и эксплуатационные. Особое внимание обращалось на необходимость использования в государственном масштабе защитной роли лесов:

- лесная защита почвы, сельского хозяйства и населенных мест и сохранение влияния лесов на климат;

- защита истоков рек, улучшение водного режима берегов;

- укрепление песков и оврагов;

- интересы гигиены;

- эстетические и культурные задачи.

Таким образом, к защитным наряду с другими категориями относились водорегулирующие и защитно-водоохранные леса, которые защищали истоки рек от обмеления и берега от разрушения. В защитных лесах пользование древесиной было ограничено, а рубки главного пользования запрещены.

В 1921 году в постановлении «О борьбе с засухой» Центральному лесному отделу было поручено провести облесительные работы по берегам и верховьям рек и ограничить рубку леса. В 1923 году утвержден «Лесной кодекс», согласно которому весь государственный лесной фонд подразделен на леса общегосударственного и местного значения. В свою очередь, общегосударственные леса разделялись на леса собственно государственные и особого назначения. В последних выделялись защитные леса, к которым, наряду с другими категориями, относились леса, предохраняющие реки от понижения уровня воды, а также охраняющие берега рек и водных источников от обвалов, размывов и повреждений ледоходом.

Постановлением СНК СССР от 31 июля 1931 года «Об организации лесного хозяйства» в целях регулирования вырубки леса, лесовозобновления, улучшения водного режима рек, борьбы с обмелением Волги, Дона и Днепра, а также борьбы с оврагами и песками в засушливой зоне все леса СССР были разделены на две зоны: лесокультурного и лесопромышленного значения. Для предохранения рек от обмеления леса в пределах однокилометровой полосы по каждому берегу среднего и нижнего течения рек Волги, Дона, Днепра, Урала в лесокультурной и лесопромышленной зонах признавались водоохранными. В них разрешалась только выборка перестойного и сухостойного леса. Согласно этому постановлению в 1935 году выделено около 13 млн. га водоохранных лесов. Учитывая особое значение лесов в регулировании водного режима рек, постановлением СНК СССР от 3 июля 1936 года выделена водоохранная зона, включающая все лесные массивы в бассейнах рек Волги, Дона, Днепра со всеми их притоками, а также леса Винницкой и Одесской областей. В водоохранной зоне вдоль берегов рек выделялись «запретные полосы». В них запрещалось проводить рубки главного пользования и допускались санитарные и рубки ухода. Запретные полосы шириной 20 км по каждому берегу были выделены (табл. 1):

- в верхних течениях рек Днепра и его притоков, Березины, Дона и его притоков, Донца, Волги и ее притоков, Молочи, Оки, Клязьмы, Камы, Белой, Вятки;

- на всем протяжении пяти рек: Десны, Воронежа, Оскола, Шексны и Москвы. 
Запретные полосы шириной 6 км по каждому берегу выделялись вдоль среднего и нижнего течений рек, указанных в первом пункте, а также по 15 притокам Волги, Дона, Днепра, Оки и Урала.

Таблица 1

Распределение площадей запретных полос (на 1936 г.) различной ширины по бассейнам рек

\begin{tabular}{|l|c|c|c|c|c|}
\hline \multirow{2}{*}{ Бассейны рек } & $\begin{array}{c}\text { Водные источники, } \\
\text { количество штук }\end{array}$ & \multicolumn{3}{|c|}{ Площадь запретных полос (тыс. га) шириной } \\
\cline { 3 - 6 } Волга & 20 км & 6 км & 4 км & всего \\
\hline \multirow{2}{*}{$\begin{array}{c}\text { реки, 57 } \\
\text { озера, 7 } \\
\text { водохранилища, 3 }\end{array}$} & 7369 & 3421 & 1058 & 11848 \\
\hline Днепр & $\begin{array}{c}\text { реки, 10 } \\
\text { водохранилища, 5 }\end{array}$ & 1408 & 578 & 222 & 1108 \\
\hline Дон & реки, 8 & 454 & 600 & 13 & 1067 \\
\hline Урал & реки, 3 & 135 & 389 & 0 & 524 \\
\hline Западная Двина & реки, 1 & 191 & 137 & 0 & 328 \\
\hline \multicolumn{1}{|c|}{ Всего } & $\begin{array}{c}\text { реки, 79 } \\
\text { озера, 7 } \\
\text { водохранилища, 8 }\end{array}$ & 9557 & 5125 & 1293 & 15975 \\
\hline
\end{tabular}

Площадь лесов водоохранной зоны изменялась последующими постановлениями правительства, как в результате присоединения, так и за счет исключения площадей лесного фонда при переводе их в другой вид угодий.

В 1956 году площадь лесов запретных полос по сравнению с 1949 годом увеличилась на 9,5 млн. га и составила 29,1 млн. га. За 7 лет (с 1949 по 1955 г.) запретные полосы шириной от 250 м до 6 км были выделены по берегам около 320 рек. Кроме того, запретные полосы шириной от 250 м до 3 км были выделены примерно по 50 озерам, каналам и водохранилищам. Ширину запретных полос по водохранилищам, образующимся по рекам, определяли в размере ширины полос, установленной для соответствующей реки.

Закон «Об охране природы» от 27 октября 1960 года отметил большую водоохранно-защитную роль леса и указал на необходимость его сохранения как важной части географической среды. Этим законом запрещались рубки водоохранных, водорегулирующих, защитных лесов и разрешались рубки только в целях ухода за лесом. Закон обратил особое внимание на необходимость регулирования режима рек, а также охраны вод от истощения, загрязнения и засорения.

В настоящее время в Украине запретные полосы выделены по берегам рек, озер, водохранилищ на площади 307,9 тыс. га; леса, выполняющие защитные функции, - на площади 1181,9 тыс. га.

В 2006 году принят «Лісовий кодекс України», в котором приведен перечень лесов, относящихся к защитной категории. К защитным относятся водорегулирующие и защитно-водоохранные леса, охраняющие реки, водохранилища, озера от понижения уровня воды и берега от разрушения.

\section{Водоохранно-водорегулирующая роль лесов}

Лесам закрытых полос вдоль рек с самого начала их выделения придавалось различное целевое назначение.

М. Е. Ткаченко [30] леса запретных полос, выделенные в 1931 и 1936 годах, относил к водоохранно-защитным. Как отмечает К. К. Зеров [9], запретные полосы имеют многообразное значение, охватывающее весь перечень водоохранных и защитных свойств, поэтому обычно считается, что основное значение запретных полос - регулиро- 
вать водный режим рек и водохранилищ. М. И. Львович [19] указывает, что одним из основных аргументов для выделения лесных защитных полос вдоль рек послужило представление о том, что леса, примыкающие к рекам, обладают более высокой водорегулирующей способностью, чем леса, расположенные вдоль них. Научный анализ влияния лесонасаждений на поверхностный сток представлен в работах $[3 ; 20 ; 23 ; 28 ; 32]$.

По данным М. И. Львовича [18], от 80 до 93 \% стока воды формируется за пределами защитных полос, проходит через них транзитом в виде сосредоточенных речных потоков, на которые влияние полога леса, расположенного вдоль рек, уже не распространяется. А. А. Молчанов [22] отмечает, что 85-90 \% стока формируется за пределами запретных полос, поэтому они не оказывают никакого влияния на сосредоточение потока вод, проходящих через защитные полосы. Анализируя роль лесов защитных зон, М. И. Львович [18] делает правильный вывод о том, что система запретных водоохранных лесов, занимающих лишь небольшую часть речных бассейнов, при недостаточном внимании ко всем остальным лесам, с гидрологической точки зрения не имеет значения.

Именно создание комплекса защитных лесных насаждений в сочетании с защитными сельскохозяйственными и инженерными мерами может привести к ожидаемому эффекту. Исходя из того, что все леса являются водоохранными, наиболее важный показатель их влияния на сток рек - мелиоративная лесистость водосбора и характер размещения лесов по бассейнам рек. А. Р. Константинов [14; 15] установил зависимость увеличения осадков от дополнительной шероховатости земной поверхности и лесистости территории. Влияние лесистости на сток рек, оптимальная лесистость, водоохранное размещение лесов на водосборах рассматриваются в работах многих ученых $[1 ; 7 ; 8 ; 13 ; 24 ; 27]$.

Изучая эти работы, можно отметить, что по вопросам влияния леса на сток рек, оптимальной лесистости водосборов и размещения лесов по ним имеются различные мнения. Однако все они говорят о том, что, характеризуя водорегулирующую роль леca, следует рассматривать с этой точки зрения все леса на водосборе реки, а не только полосы вдоль берегов [11].

Водоохранные леса на равнинных территориях разделяют на три группы:

- водоохранные - леса истоков рек, способствующие более равному поступлению воды в источники и предохраняющие реки и водоемы от засорения и загрязнения;

- водорегулирующие - леса, смягчающие наводнения, предотвращающие заболачивание;

- водоохранно-защитные - выполняющие одновременно функции водоохранности.

Леса запретных полос, произрастающие на приречной территории, выполняют большую защитную роль. С самого начала существования водоохранных лесов запретных зон до настоящего времени не было и нет научно обоснованных рекомендаций по выделению таких лесов. Шаблонное выделение запретных полос приводит к тому, что в них включаются большие площади лесов, которые не способны перевести поверхностный сток во внутрипочвенный даже на своей территории. По мнению А. А. Молчанова [22], основным недостатком при выделении водоохранных лесов был шаблонный подход, при котором отсутствовали натурные исследования, крайне необходимые при решении этого вопроса. С водоохранной точки зрения существующие защитные зоны установлены без всякого основания и расчетов.

Таким образом все леса, к какой бы категории они ни относились, выполняют водоохранные функции. Основные водоохранную, водорегулирующую и защитную функции выполняют лесные насаждения в комплексе с другими лесами и инженерны- 
ми сооружениями в защитной зоне. Защитные полосы вдоль водоемов с целью перехвата поверхностного стока со всей площади водосбора свои функции выполняют не полностью (10-15 \%). Поэтому вдоль рек и водоемов необходимо выделять защитные леса в самостоятельную категорию. Это обосновывается главным образом их особой противоэрозионно-аккумулятивной ролью, а не водоохранными функциями в регулировании поверхностного стока на водосборах.

\section{Процессы почвенной эрозии прибрежных зон водохранилищ}

Защита крупных водохранилищ от заиления продуктами смыва и размыва почвогрунтов на водосборах и от разрушения волнобоем берегов является очень важной государственной задачей. Известны примеры, когда из-за непринятия соответствующих мер по защите крупных водохранилищ от заиления они за сравнительно короткий срок выходили из строя. По данным Г. А. Харитонова [31], Штеревское водохранилище в Донбассе заилилось в течение пяти лет на 85 \%, а водохранилище Ак Су в Дагестане в течение трех лет почти полностью. Несмотря на значительную облесенность верхней части водосбора Днепрогэса, энергетическая мощность его снижается по причине частичного заиления. В Катта-Курганском водохранилище (Узбекистан), объем которого равен 650 млн. м ${ }^{3}$, ежегодно поступает 34 млн. м³ наносов [25]. По исследованиям Е. Ф. Семенова [29], в Цимлянском водохранилище за пять лет эксплуатации отложилось около 144 млн. м ${ }^{3}$ мелкозема, причем свыше 75 \% - за счет материалов обрезки берегов. За первые четыре года эксплуатации Горьковского водохранилища в него обрушилось в результате обрезки берегов около 15 млн. т грунта [4].

В Куйбышевское водохранилище, водосборный бассейн которого равен около 1,2 млн. км ${ }^{2}$, ежегодно через основные реки поступает примерно 21 млн. м ${ }^{3}$ твердых наносов. Большой объем ила отлагается в результате разрушения берегов волнобоем. Широкое водное пространство (до 40 км) способствует образованию ветровых волн высотой 3 м, которые, набегая на берег, разрушают его [21]. Возникла необходимость защиты водохранилища Волжской ГЭС от заиления продуктами смыва и размыва почвы. Твердые выносы поступают в него в основном за счет роста действующих оврагов и смыва почвы с прилегающих склонов [26].

По данным Н. М. Куницы [17], источниками заиления Каховского водохранилища являются поверхностный смыв почво-грунтов с прибалочных, приовражных и приводоохранных склонов, овражно-балочные эрозии почвы, продукты абразивного разрушения берегов, оползневые процессы.

Основными участками поступления твердого стока в Днепродзержинское водохранилище следует считать непосредственно впадающие в него крупные и мелкие овражно-балочные системы, рытвины и ложбины, расположенные на самом берегу, береговые склоны, опускающиеся к чаше, и расположенные в них мелкоструйчатые размывы. Бассейн Днепродзержинского водохранилища (36,2 тыс. га) включает в себя впадающие в него овражно-балочные системы с их водосборами, а также опускающиеся к водохранилищу склоны. По интенсивности эрозии водосборный бассейн водохранилища разделяется на три категории: слабо-, средне- и сильноэродированные. Слабоэродированная часть водосборного бассейна приурочена к равнинным площадям приводораздельных склонов. Среднеэродированная часть водосборного бассейна характеризуется сильной расчлененностью балками. Она тянется прерывистыми полосами по правому и левому берегам водохранилища. Сильноэродированная часть в основном расположена на правом берегу, включает в себя Днепровскую (11079 га), Домоткан- 
скую (7604 га) овражно-балочные системы и занимает площадь свыше 36 тыс. га; Самотканская - 10702 га, Омельчанская - 7742 га [10].

Кроме эрозионных процессов, разрушение берегов водохранилища и его заиления вызывают абразивные процессы. Абразия берегов Днепродзержинского водохранилища и ее последствия громадны. Большой объем ила образуется в результате разрушения берега волнобоем. В этом сказывается большая его ширина, которая определяет разгон волны и ее гидродинамические свойства. Из общей береговой линии (760 км) 540 км подвержены разрушению берегов. Процессы переработки берегов особенно выражены в правобережной части водохранилища и сопровождаются оползневой деятельностью, на многих участках образуются трещины и просадки берега. Вред от абразии заключается не только в потере земельной площади, но и в сложности переноса капитальных строений и коммуникаций, расположенных вдоль береговой линии [12].

Методы и приемы, применяемые в борьбе с заилением крупных водохранилищ, весьма разнообразны, сложны, поэтому требуется комплекс защитных мер, который должен распространяться на водосборную и береговую часть водохранилища, а также на прилегающие к ним земли. В основе создания защитной зоны Днепра Ю. П. Бяллович [5] выделяет четыре группы фитомелиорации: сельскохозяйственную, инженерную, природоохранную и гуманитарную (табл. 2).

Основные виды фитомелиорации защитной зоны Днепра (по Ю. П. Бялловичу)

Таблица 2

Наименование целевых групп фитомелиорации

\begin{tabular}{|c|c|c|c|}
\hline \multicolumn{4}{|c|}{ Наименование целевых групп фитомелиорации } \\
\hline $\begin{array}{c}\text { сельско- } \\
\text { хозяйственная }\end{array}$ & инженерная & природоохранная & гуманитарная \\
\hline $\begin{array}{l}\text { Направлена на соз- } \\
\text { дание наилучшей } \\
\text { жизненной среды } \\
\text { для сельхозкультур } \\
\text { и животных. В за- } \\
\text { дачи сельско- } \\
\text { хозяйственной фи- } \\
\text { томелиорации вхо- } \\
\text { дит формирование } \\
\text { благоприятного } \\
\text { микроклимата, со- } \\
\text { хранение почвы и } \\
\text { повышение ее пло- } \\
\text { дородия }\end{array}$ & $\begin{array}{l}\text { Направлена на улучшение } \\
\text { условий эксплуатации раз- } \\
\text { личных инженерных соору- } \\
\text { жений, находящихся под } \\
\text { воздействием географиче- } \\
\text { ской среды и образующих } \\
\text { инженерно-природные сис- } \\
\text { темы. Ставятся задачи: обес- } \\
\text { печение непрерывности экс- } \\
\text { плуатации сооружений, уве- } \\
\text { личения сроков их амморти- } \\
\text { зации, уменьшения расхода } \\
\text { энергии }\end{array}$ & $\begin{array}{l}\text { Направлена на сохранение } \\
\text { возобновляемых природных } \\
\text { ресурсов. К возобновлению } \\
\text { относятся те ресурсы, исто- } \\
\text { щение которых при эксплуа- } \\
\text { тации не является неизбеж- } \\
\text { ным и при правильной их } \\
\text { эксплуатации восстанавли- } \\
\text { ваются и даже улучшаются. } \\
\text { Возобновляемыми природ- } \\
\text { ными ресурсами являются } \\
\text { воздушные и водные массы, } \\
\text { качество почвы и др. }\end{array}$ & $\begin{array}{l}\text { Направлена на улучше- } \\
\text { ние географической сре- } \\
\text { ды для человека, улуч- } \\
\text { шение водно-санитар- } \\
\text { ного и воздушно-сани- } \\
\text { тарного режимов, на } \\
\text { формирование микро- } \\
\text { климата, повышение } \\
\text { эстетики ландшафта. } \\
\text { Эти задачи она решает в } \\
\text { форме создания природ- } \\
\text { ной базы для развития } \\
\text { обширных зон отдыха }\end{array}$ \\
\hline
\end{tabular}

Исследуя защитную зону Днепродзержинского водохранилища и используя научный и практический опыт, мы предлагаем экологические принципы создания защитной зоны Днепродзержинского водохранилища (табл. 3). Эти принципы сводятся к трем видам фитомелиорации: сельскохозяйственной, лесохозяйственной и инженерной [12].

Задачи, поставленные перед фитомелиорацией защитной зоны Днепродзержинского водохранилища, не могут решаться в рамках одной из трех фитомелиоративных групп. Здесь необходим обширный фитомелиоративный комплекс, включающий в себя многочисленные виды фитомелиорации. Нами разработаны основные принципы устройства лесной защитной зоны. Лесная часть защитной зоны должна занимать земли, не пригодные для сельскохозяйственного производства, ценность которых не будет потеряна под влиянием береговых процессов и оврагообразования. В лесную часть защитной зоны включаются также те площади мелководий, которые могут быть использованы для создания лесных культур продолжительнопоемного характера. Верхняя 38 
граница защитной зоны Днепродзержинского водохранилища не параллельна урезу воды, а идет по извилистым рубежам оползнеопасных, эродируемых, развеваемых и других неудобных земель или по опушкам существующих прибрежных лесных массивов. Для нижних береговых защитных культур основными задачами являются защита побережья от абразии, защита поймы от размыва. Средние береговые лесные насаждения предохраняют почвы от эрозии и оползней на береговых откосах. Верхние береговые насаждения предупреждают эрозионные процессы и служат рекреационной зоной. Все перечисленные виды защитных лесных насаждений характерны для защитной лесной зоны Днепродзержинского водохранилища, хотя в практике лесоводства такая дробность насаждений просто затруднена.

Таблица 3

Экологические принципы создания защитной зоны Днепродзержинского водохранилища

\begin{tabular}{|l|l|l|}
\hline Сельскохозяйственная защитная зона & \multicolumn{1}{|c|}{ Лесная защитная зона } & \multicolumn{1}{|c|}{ Инженерная защитная зона } \\
\hline $\begin{array}{l}\text { Противоэрозионная } \\
\text { организация территории }\end{array}$ & нижние береговые культуры & ступенчатые террасы \\
\hline $\begin{array}{l}\text { Почвозащитные } \\
\text { севообороты }\end{array}$ & средние береговые культуры & $\begin{array}{l}\text { водозадерживающие } \\
\text { и водоотводящие валы }\end{array}$ \\
\hline $\begin{array}{l}\text { Противоэрозионная } \\
\text { агротехника в полеводстве }\end{array}$ & верхние береговые культуры & донные сооружения в оврагах \\
\hline $\begin{array}{l}\text { Противоэрозионная } \\
\text { агротехника в садах }\end{array}$ & овражно-балочные культуры & планировка и засыпка оврагов \\
\hline $\begin{array}{l}\text { Противоэрозионные } \\
\text { лесные насаждения }\end{array}$ & пруды-отстойники \\
\hline
\end{tabular}

В целях достижения экологической устойчивости лесной защитной зоны для преодоления эрозионных, оползневых и других неблагоприятных процессов здесь необходимо применять от простейших до сложных гидротехнических сооружений:

- в нижних, береговых насаждениях - осушительные канавы;

- в средних береговых насаждениях - террасирование, устройство водоотводящих валов;

- в верхних и овражно-балочных насаждениях - строительство инженерных гидротехнических сооружений.

Кроме того, нами предлагаются возможные профили канав, совмещенные с лесными насаждениями в лесной защитной зоне Днепродзержинского водохранилища.

Наименьшей шириной лесной части защитной зоны по одному берегу, не считая островной поймы, по мнению Ю. П. Бялловича [6], следует принять 100 м. Однако, учитывая современное состояние береговой части Днепродзержинского водохранилища, особенно правобережье, где наблюдается постоянный волнобой и процессы оврагообразования, минимальную ширину защитной зоны необходимо удвоить.

Наибольшей ширины (в несколько километров) защитная зона достигает в местах с крупными процессами древней и современной эрозии - оползнями и другими неблагоприятными явлениями. Примером этого может быть Домотканская система оврагов и

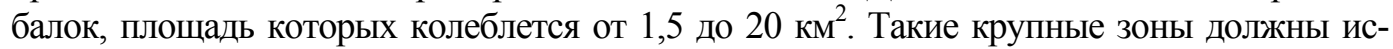
пользоваться для формирования прибрежных государственных лесопарков, которые выполняют все защитные функции и являются ее главными фитомелиоративными участками. На этих участках устраиваются базы отдыха, пионерские лагеря, оздоровительные центры. Экологические условия в защитной зоне водохранилища сильно изменяются по мере удаления от уреза воды. Поэтому напротив любого отрезка береговой линии необходимо размещать серию различных видов лесных насаждений [9]. 
Экологическая оценка созданных защитных лесонасаждений определяется суммой величин годового прироста показателей улучшения деятельности сельскохозяйственных предприятий и предотвращения ущерба от эрозионных процессов, происходящих на берегах Днепродзержинского водохранилища. Эффективность защитных лесных насаждений водохранилища определяется с учетом основных защитных функций.

\section{Выводы}

Приовражные и прибалочные полосы сочетаются с полезащитными полосами и насаждениями на оврагах, балках и вокруг водохранилищ в единую систему и в сочетании с гидротехническими сооружениями образуют лесоаграрный комплекс. Верхние береговые защитные лесонасаждения водохранилища непосредственно соприкасаются с прилегающими полями и оказывают на них существенное влияние. В экологическом комплексе полезащитные приовражные и прибалочные насаждения защищают поля от суховеев и пыльных бурь, чем положительно влияют на повышение урожайности сельскохозяйственных культур. С целью повышения экологической безопасности страны необходимо разработать компенсационную программу по защите как крупных водоемов, так и малых рек от неблагоприятных природных факторов и увязать эти меры с формированием экологической сети Украины.

\section{Библиографические ссылки}

1. Бодров В. А. Пути разрешения проблемы борьбы с засухой в районе Каневских дислокаций // Научн. тр. УСХА. - К., 1957. - Т. 9. - С. 191-196.

2. Бочков А. П. Влияние леса и агролесомелиоративных мероприятий на водность рек лесостепной зоны Европейской части СССР. - Л.: Гидрометеоиздат, 1954. - 133 с.

3. Бочков А. П. Нормативы по учету влияния агролесомелиоративных мероприятий на сток. - Л.: Гидрометеоиздат, 1963. -7 с.

4. Бросалов В. А. Горьковскому морю - зеленые берега // Лесное хоз-во. - 1960. - № 2. - С. 4-6.

5. Бяллович Ю. П. Фитомелиорация лесной части защитной зоны Днепра // Защитная зона Днепра. - К.: УСАН, 1962. - С. 26-81.

6. Бяллович Ю. П. Защитные насаждения по берегам крупных водохранилищ и судоходных рек // Лесные насаждения. - М.: Сельхозиздат, 1963. - С. 409-450.

7. Веткалов В. К. Подбор пород для противоэрозионных насаждений в зоне Волжской ГЭС // Лесное хоз-во. - 1958. - № 12. - С. 29-33.

8. Воскобойников В. М. Динамика берегов Каховского водохранилища в первые пять лет эксплуатации // Tp. VII Байкал. совещ. - М., 1961. - Т. 1. - С. 69-78.

9. Горейко В. А. Лесные насаждения в комплексе экологических противоэрозионных мероприятий // Питання степового лісознавства та лісової рекультивації земель. - Д.: ДНУ, 2003. - C. $154-170$.

10. Горейко В. А. Лісова рослинність яруго-балкових систем Верхньодніпровського регіону // IV з'їзд Українського ботанічного товариства. - К.: Наукова думка, 1992. - С. 99-101.

11. Горейко В. А. Экологическая стабилизация овражно-балочных ландшафтов в условиях степной зоны Украины // Екологія кризових регіонів України. - Д.: ДНУ, 2001. - С. 23-24.

12. Зайщев В. Т. Почвозащитная роль лесных полос и пути ее усиления // Лесное хоз-во. 1961. - № 3. - C. 24-28.

13. Зеров К. К. Формирование растительности и разрастание водохранилищ Днепровского каскада. - К.: Наукова думка, 1976. - 131 с.

14. Константинов А. Р. Испарение в природе. - Л.: Гидрометеоиздат, 1966. - 532 с.

15. Константинов А. Р. Лесные полосы и урожай. - Л.: Гидрометеоиздат, 1965. - 176 с.

16. Куница Н. М. Защитные лесные насаждения на Каховском водохранилище и на орошаемых землях юга Украины // Лесное хоз-во. - 1987. - № 6. - С. 40-44. 
17. Куница Н. М. Зеленый щит Каховского водохранилища // Лесное хоз-во. - 1974. - № 9. C. $57-60$.

18. Львович М. И. Мировые ресурсы и их будущее. - М.: Мысль, 1974. - 448 с.

19. Львович М. И. Эффективность защитных водоохранных полос леса вдоль рек и проблема их эксплуатации // Известия Всесоюзного географического общества. - 1958. - № 5. - С. 15-24.

20. Міхович А. Г. Водоохоронні лісонасадження. - К.: Урожай, 1986. -119 с.

21. Мамаев С. А. Опыт проектирования защитных лесонасаждений на берегах Куйбышевского водохранилища // Изв. ТСХА. - 1958. - Вып. 2. - С. 175-184.

22. Молчанов А. А. Гидрологическая роль леса. - М.: Изд-во АН СССР, 1960. - 468 с.

23. Молчанов А. А. Гидрологическая роль полезащитных полос и методика ее изучения. - М.: Изд-во АН СССР, 1962. - 188 с.

24. Орел Г. М. Из опыта облесения берегов Кременчугского водохранилища // Лесное хоз-во. 1963. - № 9. - С. 34-38.

25. Полонская Л. С. Зеленые насаждения Катто-Курганского водохранилища. - Волгоград, 1962. - С. 27-31.

26. Росторгуев Л. И. Приемы, предотвращающие заиление Волгоградского водохранилища // Вестник с.-х. науки. - 1962. - № 8. - С. 110-113.

27. Рахманов В. В. Водоохранная роль лесов. - М.: Гослесбумиздат, 1962. -235 с.

28. Ревера О. 3. Сток малых водоемов // Тр. УкрНИИГМИ. - Л.: Гидрометеоиздат, 1965. Вып. 51. - С. 39-46.

29. Семенов Е. Ф. Некоторые результаты изучения формирования берегов и ложа Цимлянского водохранилища // Тр. VII Байкал. научн. совещ. - М., 1961. - Т. 1. -C. 37-46.

30. Ткаченко М. Е. Общее лесоводство. - М.-Л.: Гослесбумиздат, 1939. - 746 с.

31. Харитонов Г. А. Эрозия в районе Цимлянского водохранилища и мероприятия по защите водохранилища от заиления // Записки Воронеж. ЛХИ. - 1952. - Т. 13. - С. 11-26.

32. Шпак И. С. Влияние леса на водный баланс водосборов. - К.: Наукова думка, 1968. - 284 с.

Надійшла до редколегії 31.01.2008 